\title{
Plastic recycling and waste reduction in the hospitality industry: Current challenges and some potential solutions
}

\author{
Abel Ramirez *(D), Babu George ** \\ *William F. Harrah College of Hospitality, \\ University of Nevada Las Vegas, \\ 4505 S. Maryland Pkwy, Las Vegas, Nevada, USA \\ E-mail: ramir183@unlv.nevada.edu \\ ** Robbins College of Business and Entrepreneurship, \\ Fort Hays State University, \\ Hays, Kansas, USA \\ E-mail: bpgeorge@fhsu.edu
}

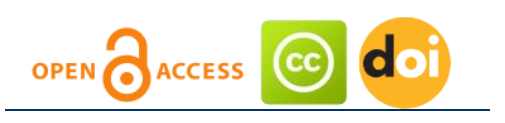

Article history:

Received: January 29, 2019

1st Revision: February 12,

2019

Accepted: April 05, 2019

\section{JEL classification: \\ Q53 \\ Q56 \\ Q57}

\section{DOI:}

10.14254/jems.2019.4-1.1

\begin{abstract}
Every year, the hospitality industry creates millions of tons of avoidable waste globally. While conspicuous consumption is the hallmark of the industry, leaders of the industry have come to the realization that it cannot go on forever. Added to that, the surge of eco-conscious guests and other pressure groups provide the industry players an increased level of impetus for introducing positive change in terms of waste reduction and recycling. Employing a combination of systematic literature review and grounded case studies, this paper addresses the current effort the hospitality industry is undertaking to reduce waste and recycle plastic goods and the challenges to be overcome in that process. To explain the contemporary practice, it brings in examples of hotels, resorts, and restaurants chains that are presently implementing recycling or reducing waste programs.
\end{abstract}

Keywords: Ecology, environment, hospitality, tourism, plastic waste, recycling, sustainability.

\section{Introduction}

There are traces in ancient times of sustainability practices, and as the overall world's population keeps increasing, consumption of resources increases as well. The consequences of the Industrial Revolution, between 1820 and 1840, left in great danger crucial resources because they were diminishing. Those resources include wood, coal and oil; therefore, this situation created an awareness on how to use these crucial resources in an efficient and sustainable way (Du Pisani, 
2006). Sustainable development is now a discipline on its own, yet the application of the generic theory of sustainability into tourism - hospitality fields remains underexplored and to some extent remains problematic (Korstanje \& George, 2012). We do know a lot about recycling and reuse of resources in specific industries; yet, tourism being an inter-industrial-domain of professional practice (or, a derivative of several industries), the application of generalized knowledge is not selfevident. The purpose of this paper is to fill this gap.

According to Wenche, Tuomas, Kirsi, Andreas, and Bjorn (2017), contemporary businesses are under pressure to incorporate sustainability principles in their daily operations process and turn objectives into policies. Governments are more aware of the importance of recycling and the importance of encouraging every citizen can do his part. For example, the state of California has implemented laws banning the use of plastic bags in some of its beaches due to pollution, Californians would be obligated to stop using plastic bags near the beaches. An article describes how Manhattan Beach created a law to ban the sale of plastic bags in order to avoid pollution of the beaches (Diaz, 2012).

The last few decades have allowed a growing awareness among the hospitality industry and investors regarding ecological concerns impact the guests as well as hotel operations (Hillier, and Comfort, 2014; Jones et al., 2014). Several companies are implementing sustainable measures in order to reduce the usage of resources and waste thereof in their respective properties (Korstanje \& George, 2012). There has been a movement towards sustainability by the general population, businesses and governments after the publication of the "World Conservation Strategy" ("International Union for the Conservation of Nature and Natural Resources," 1980), the content explains how the population has been implanting new strategies in how to recycle plastic and to reduce the waste.

To minimize the problems of global warming and climate change, plastic usage must be reduced since it is one of the greatest contributing factors ("Anonymous, Eliminating Bottled Water," 2009). The hospitality industry must consider how a business will operate if laws banning the use of plastic are implemented by the government. The legislatures in various nations are discussing the possibilities available to eliminate plastic waste as much as possible. The government in the United Kingdom is considering plans to decrease as much plastic waste as possible by 2042, but nothing is concrete since no legislation has been passed. Businesses in all industries must be proactive in reducing plastic usage and waste and implementing recycling policies in order to avoid having to undertake drastic and costly changes to business operations once laws have been passed (Le Page, 2018).

Using a combination of systematic literature review and grounded case studies from the hospitality industry, this paper examines the different dimensions of plastic waste recycling. Peerreviewed articles relevant to the topic were subjected to meta-analysis. Insights from the literature were placed against the waste recycling practices currently being used by some of the key players in the industry.

\section{Waste management through recycling}

In order to recognize sustainability - recycling connection better, it is important to understand the process of recycling. Since this discussion focuses on plastic recycling and reducing plastic waste, it is helpful to know the steps to recycle and reduce this item, as it may make people conscious of its use, those especially who abuse the use of plastic. In a report named "waste plastic recycling process", Liu \& Min (2012) explains the process:

1. Crushing waste polyethylene plastic, cleaning with a washing barrel, rinsing again in a water tank, drying, and obtaining waste polyethylene plastic particles.

2. Raw polyethylene and polyethylene plastic waste are mix uniformly with activators, compatilizers, plasticizers, antioxidants and lubricants, carrying out plasticization and filtration, and finally cutting to obtain granulated plastic. Thin-film or single-use plastic bags are made up of a high-density material called polyethylene, and the low-density polypropylene material is used for thicker plastic bags with fiber handles (Wagner, 2017).

The existing recycling processes and technologies focus on thermoplastics and taking advantage its ability to process materials in high-temperature melt state (Garcia \& Robertson, 2017). There are some limitations to these processes, which can be overcome with newer technology and developments, for example polymers that reverse or exchange at an elevated temperature. A newer process like this will allow the reworking of materials before they need to be reuse or recycle. According to Garcia and Robertson (2017) polymers can undergo in chemical, thermal, photo-, or biodegradation process that might turn the material into a new product only if the material goes under complete depolymerization-repolymerized (see Figure 1). 


\section{Figure 1: Repeatedly recyclable polymers}

\section{Repeatedly recyclable polymers}

Zhu et al. report production of a plastic that can be recycled repeatedly through chemical methods without loss of function. Blending of the two enantiopure polymers yields a plastic that can withstand higher temperatures, expanding its usefulness further.

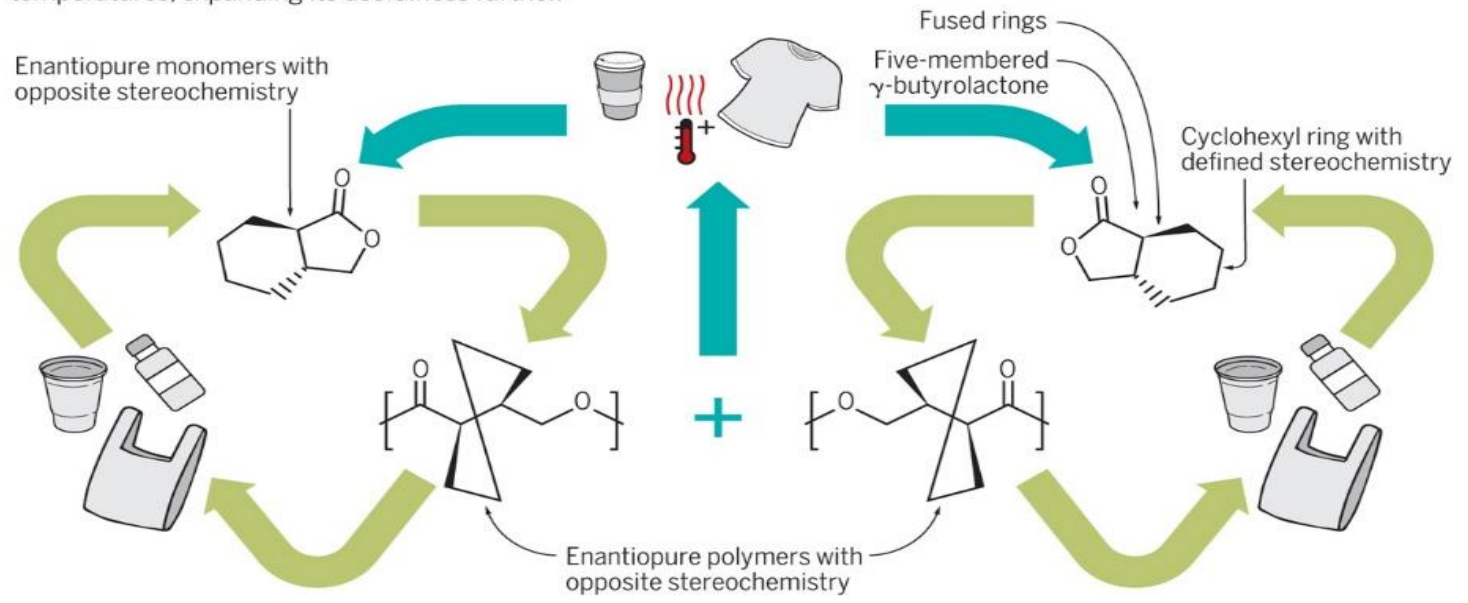

Source: Sardon \& Dove (2018)

In the recent past, researchers have worked on an alternative sustainable strategy that would get rid of plastic waste by using chemicals that allow solids to be recycled into raw materials again. The plastic would have the same properties as the original and would not need new monomer feedstock (Sardon \& Dove, 2018). This strategy will help with the environmental issues related to plastic waste as well as the continual demand of raw materials to produce new plastic items. Plastic can be submitted into three different recycling types: energy recycling is one of them, this recycling process is achieved by burning the plastic and turning the burned material into energy, the other two types are chemical and mechanical (Pacheco, Ronchetti, \& Masanet, 2012).

\section{Societal perspectives on recycling and waste reduction}

There are five active generations in the American workforce: The Silent Generation also known as Baby Boomers; Generation X; Xennial; Millennials; and Gen Z (see Table 1). The impact each generation has on the economy, workforce and hospitality industry highlights the importance of analyzing them. Below is a chart that breaks down the percentage of each generation in the workforce and power they have in the American society (Zisman, 2018). Each generation has its own view and thus, a different reaction to ideas or strategies in the hospitality industry. While one generation may interpret the strategy as being helpful to the environment, applauding hotels for being green: on the other hand, another generation may view these efforts as the hotel merely wanting to save some extra money at the expense of the guest, who receives lower quality services.

\begin{tabular}{|c|c|c|c|c|}
\hline $\begin{array}{l}\text { Traditionalist or The } \\
\text { Silent Generation }\end{array}$ & Baby Boomers & Generation X & Millennials/Generation Y & Generation $\mathrm{Z}$ \\
\hline Born:1928-1945 & Born:1946-1964 & $\begin{array}{c}\text { Born: 1965- } \\
1980\end{array}$ & Born:1981-1997 & $\begin{array}{c}\text { Born:1998- } \\
\text { Present }\end{array}$ \\
\hline Age:71-89 & Age:53-70 & Age:37-52 & Age:19-36 & Age:0-18 \\
\hline $2 \%$ of U.S. Labor Force & $\begin{array}{l}29 \% \text { of U.S. } \\
\text { Labor Force }\end{array}$ & $\begin{array}{l}34 \% \text { of U.S. } \\
\text { Labor Force }\end{array}$ & $34 \%$ of U.S. Labor Force & $\begin{array}{l}1 \% \text { of U.S. } \\
\text { Labor Force }\end{array}$ \\
\hline
\end{tabular}

Source: Zisman, J., 2018, 03.

\subsection{Social classes and their perceptions}

Millar and Baloglu (2011), discussed a study conducted with 571 participants, 282 were business travelers and 287 were leisure travelers. The study measured and categorized each participant's gender, age, educational level, household income and marital status. The categories were created in order to determine how it would influence their view of a hotel with eco-friendly program. The business travelers' demographic profiles included 165 males and 119 females; 64 
were Millennials and Generation Z, 147 were Generation X and 73 were Baby Boomers. The leisure travelers' demographic profile included 124 males and 163 females; 56 Millennials and Generation Z, 141 were Generation X and 90 were Baby Boomers. The study found business and leisure travelers preferred to book an eco-friendly hotel with recycling policies, controlled lighting and energy efficient light bulbs; these travelers were not concerned with green certification, linen and towel policies (Millar \& Baloglu, 2011). It is evident that guests are aware of a hotel's efforts to be sustainable and eco-friendly since these factors are taken into consideration at the time of making a room reservation, especially if a recycling policy or program is in place.

It will not be surprising to statutes or regulations in the future to plastic products as some states such as New York, California and Hawaii are currently considering creating laws to ban the use of straws. Some cities like Seattle, Miami Beach, Oakland, and a dozen others are banning or limiting the use of straws by establishing a regulation for all businesses to provide straws to its customers only upon request, as opposed to having them inaccessible areas (Povich, 2018). According to a 2015 study, single-use plastic straws only make up four percent of plastic waste. This percentage is even less when weight is considered; plastic straws account for only 2000 tons of nearly nine million tons of plastic waste, indicating the need to implement or do more to recycle plastic goods (Kukulka, 2018). The article "Towards zero waste" (Holmes, 2017) states that the United States generates 31.8 million tons in used plastics per year, but only 2.8 million tons are recycled each year; only $8.8 \%$ of plastic materials are recycled.

With the passage of time, society is becoming more aware of the negative effects of plastic use for the environment. Environmental activists are vehement in educating individuals through social media about the possible resulting harm to the environment when plastic drinking straws are not properly disposed of or recycled (Kukulka, 2018). As major corporations become more conscious of the need to preserve the environment's natural resources and reduce waste, there will be a drastic change in how consumers enjoy their beverages and meals over the next couple of years (Kukulka, 2018).

\subsection{Key stakeholder groups}

In order to avoid future barriers and keep up with the motivators, it is important for a company to understand the "who," "what" and "how": "who" is the one responsible for developing, improving and sustaining the recycling program whether that means as individual $r$ business entity; "what" are partnerships that should be created; and "how" details how a business will maintain sustainability through its program. Everyone in a business, from top management to entry-level positions, plays a key role in the development of a recycling program and thus, should work in unison to ensure its success. The book "Sustainability in the Hospitality Industry" gives the following breakdown of the "who's", "what's" and "how's (Sloan et al, 2013, p.27);

$\underline{\text { WHO }}$

- Hospitality business

- Local Governments and regulators

- Educational Institutes

- Non-governmental Institutes

- $\quad$ Other Citizen groups. WHAT

- A partnership: develops conflict resolutions, harmonizes plans, creates action for improvement, shares experiences and monitors activities between partners and companies.

- Industry Responsibility: integrates sustainable thinking and commitment into boardrooms to educate teams, review communication, and takes advantages of initiatives. $\underline{\mathrm{HOW}}$

- Environmental programs regarding: energy saving, water saving, lowering emissions, and encouraging reusing recycling of materials.

- Social programs concerning: fair trade, local economic development, working conditions, avoiding corruption and increasing safety.

- Economic programs covering: accountability, transparency, corporate governance, shareholder value, tax incentives, economic performances, and financial objectives.

Guests may create barriers when it comes to participating in the efforts of an eco-friendly hotel. Guests need to have a deep understanding of why the hotel has incorporated eco-friendly measures throughout its premises. If guests have a clear understanding on the need to be ecofriendly, they will be more willing to participate, and making green programs more effective. Some of the possible barriers stopping guests' participation include: disruption during the service 
process, perceptions of cost-cutting meaningless amenities, and perception of decreased of luxury; a hotel should educate its staff to answer any questions or concerns a guest may have regarding the difference in service (Baker, Davis, \& Weaver, 2014). For example, if a hotel is no longer using straws, the staff can educate a guest about how straws can be harmful to the environment and the hotel is working to be eco-friendly and not cutting the use of straws just to reduce cost at the expense of the guests. For hotels and motels in Onondaga County, New York, it was not an easy task to educate guests about recycling and reducing waste. The county passed a law in 1990 prohibiting in the same containers; recyclable materials and trash, the law applied to homeowners, business people, hotel and motel guest; no one was exempt. The Onondaga County Resource Recovery Agency (OCRRA) took action to help the local hotels and motels find ways to educate guests about recycling. OCRRA provided free recycle bins for hotels marked with an arrow and labeled "We recycle". Also, every hotel had instructions in every guest room on how to recycle. It is no surprise that the Onondaga County has one of the nation's best recycling rates. Hotels in Onondaga County were able to see savings of three hundred dollars to five hundred dollars in disposal cost due to the success of their recycling program and the support of OCRRA ("County's waste agency helps hotels recycle," 1999).

\section{Barriers and motivators for plastic recycling in the hospitality industry}

Any industry striving to be more sustainable will face many motivators as well as barriers. Holmes (2017) breaks down seven categories of plastics that can be recycled, by percentage and he states that only a very small portion is recycled. Below is a table (Table 2) showing the seven categories along with additional information that shows the need to improve recycling efforts.

\begin{tabular}{|c|c|c|}
\hline Category & Items & Recyclable Percentage \\
\hline Polyethylene terephthalate & $\begin{array}{ll}- & \text { Bottled drinks } \\
- & \text { Fleeces } \\
\text { - } & \text { Carpets } \\
\text { - } & \text { Pillows } \\
\end{array}$ & $\begin{array}{l}19.5 \% \text { Recycled to a new container } \\
\text { and polyester fibers. }\end{array}$ \\
\hline High density polyethylene & $\begin{array}{ll}- & \text { Milk containers } \\
- & \text { Detergent bottles } \\
\text { - } & \text { Toys } \\
\text { - } & \text { Plastic bags } \\
\end{array}$ & $\begin{array}{l}10.3 \% \text { Downcycled to outdoor } \\
\text { furniture and other durables }\end{array}$ \\
\hline Polyvinyl chloride & $\begin{array}{ll}- & \text { Clear food wraps } \\
- & \text { Pipes } \\
- & \text { Cables } \\
- & \text { Toys } \\
\end{array}$ & $0 \%$ Not recyclable \\
\hline Low density polyethylene & $\begin{array}{ll}- & \text { Shrink wraps } \\
\text { - } & \text { Squeezable bottles } \\
\text { - } & \text { Grocery bags } \\
\end{array}$ & $\begin{array}{l}5.3 \% \text { Downcycled to outdoor } \\
\text { furniture, floor tiles and bin liners. }\end{array}$ \\
\hline Polypropylene & $\begin{array}{ll}- & \text { Yogurt cartons } \\
- & \text { Nappies } \\
\text { - } & \text { Bottle caps } \\
\end{array}$ & $\begin{array}{l}0.6 \% \text { Downcycled to outdoor } \\
\text { furniture, floor tiles and bin liners. }\end{array}$ \\
\hline Polystyrene & $\begin{array}{l}\text { Cups } \\
\text { Takeaway containers } \\
\text { Packaging } \\
\end{array}$ & $\begin{array}{l}0.9 \% \text { Downcycled to flowerpots, toys } \\
\text { and for construction. }\end{array}$ \\
\hline Other resins & $\begin{array}{ll}- & \text { Baby bottles } \\
\text { - } & \text { Water cooler bottles } \\
\text { - } & \text { Car parts } \\
\end{array}$ & $\begin{array}{l}22 \% \quad \text { Some Recyclables, some } \\
\text { compostable. }\end{array}$ \\
\hline
\end{tabular}

Source: Adapted from “Towards zero waste,” by Holmes, B., 2017, New Scientist, 235(3135), 42.

There are five reasons for a hospitality business to consider whether sustainability should be pursued or not, such as implementing a recycling program, plastic waste reduction program or any other eco-friendly program (Sloan et al., 2013). Table 3 shows a chart with these five pro and con reasons. 
Table 3: Five barriers and motivators for recycling and reducing plastic waste

\section{Barriers}

Motivators

1. Perceived high capital costs

2. Doubts of return on investments

3. Lack of time

4. Requires too much management

5. Limited interest/knowledge
1. Potential cost savings

2. Increased market share and image improvement

3. Acquiring competitive advantage

4. Intrinsic motivation ("doing something good")

5. Enhanced employee morale

Source: on the basis of Sloan et al., 2013. Adapted from "Sustainability in the Hospitality Industry: Principles of Sustainable Operations," by Sloan et al., (2013).

It is important to consider that those barriers could be easily taken down with the motivator's ideas. A different article describes some ideas that could be great for investors or hoteliers seeking to implement sustainable strategies and recycling programs if they do not have, some of the suggested tips or ideas to get rid of the barriers include (Sloan et al., 2009):

- Banks facilitating investment funds designed to help companies become eco-friendly. An investment fund provides three benefits to the seeking company: first, an affordable loan; second, private investors willing to invest money with the attractive rates; and last, there will be environmental benefits in the long run that will give an enhanced image to the company.

- To avoid the lack of knowledge about the finance part or green developments there are multiple websites that will help hoteliers with information regarding sustainability such as www.gen-eurpoe.org, gen.ecovillage.org/regions/index and www.epa.gov/greenbuilding/tools/funding.htm.

- The marketing image will be positive since it projects a caring and eco-friendly organization that could stand out from the competition.

- Motivating employees to join a project that has a direct impact in their professional careers and in their personal lives. Saim Bay View Pattaya Hotel in Thailand, opened a contest to employees, asking them to create art with recycled materials such plastic bottles, paper boxes and plastic bags. Employees created wonderful pieces of art, made up entirely of recycled materials. Some of the creations included: an Elvis-style dress coat made of bags, working lamps and clocks. This contest made the hotel's staff conscious about reducing and recycling plastic, cardboard and paper ("Hotel encourages staff to create a beautiful world of art using trash," 2010)

- The return on investment (ROI) will be paid in less time because there will be a higher income because of the good image and reputation and in the long run savings on business operations.

- A recycling program will aid in the control, create savings in materials and cost of energy, as well as reducing usage of resources and waste.

\section{Waste management practices: Insights from case studies}

Many companies across the globe in the hospitality industry are implementing green efforts and recycling programs. Although this paper focuses on plastic, it is only the beginning of a chain of sustainability; by saving energy the company also saves on plastic, paper, cardboard or aluminum because other companies need the previous resources mentioned above to produce new products, for example a company that produces plastic goods uses energy, water, and electricity during the production process. The following section lists some hotels and restaurants with recycling programs or some sort of sustainable program to recycle plastic, paper, cardboard, and aluminum or to preserve energy, electricity, and water.

A. Marriott International

- Water consumption is reduced by twelve percent and four percent in energy per every occupied room ("Marriott International," 2012).

- Each hotel has an online tool with a comprehensive list of environmental metrics and practices so guests could be educated in those eco-friendly practices ("Marriott International," 2012).

- $\quad$ Reduce water usage by 15 percent, carbon by 30 percent, energy waste by 45 percent, and food waste by 50 percent ("Marriott International," 2012).

- Since 2010, the Ritz-Carlton Hotel (Marriott's luxury brand) and PrimaTM created a co-branded and eco-friendly sixteen-ounce bottle. The bottle is made from $100 \%$ plants and will decompose in 30 days or can be reprocessed to make a new bottle 
("The Ritz-Carlton Hotel company introduces environmentally-friendly water bottles," 2010).

B. MGM Resorts International

- Has an energy and water conservation program in place.

- 15 properties of its have received a green key designation because of their sustainability efforts. The Green Key Eco-Rating Program Ranked and granted the green key designation award to: ARIA, Mandalay Bay, MGM Grand Las Vegas, and Vdara, just to name a few ("MGM Resorts International Joins American Business Act on Climate Pledge," 2015).

- The world's largest LEED Gold certified building is Aria Resort and Casino, which is one of MGM Resorts International property. The resort has a large recycling area and operation plan that enables it to recycle and reuse more than 260,000 tons of waste including construction material, food, plastic, paper, cardboard, plastic, and glass waste (Anonymous, 2009).

- Has implemented a sustainable supply chain and outreach efforts and education programs (“EPA Awards MGM Resorts for Food Recycling Program," 2011).

C. Hilton Inc.

- Has an existing partnership with Clean the World to recycle soap and amenity bottles in order to reduce plastic waste ("Press Release: Hilton Worldwide," 2015).

D. Anantara and Avani Brand Hotels.

- Since January 1, 2018, both hotel brands have ended their use of plastic drinking straws; just this initiative will stop the usage of 2.5 million plastic straws in the first year across all the hotels and resorts located in Asia. The companies sought out a local village in Asia processes wild bamboo, with the intent to replace plastic straws with bamboo-made straws, which will also be hygienic and reusable for guests ("Anantara, Avani Hotels to end the use of plastic straws," 2017).

E. Hyatt Hotel Corporation

- Starting on September 1, 2018 the company will implement a straw and cocktail picks policy to be available to guests only upon request. The company will provide an eco-friendly alternative (paper straws or wood cocktail picks) for those items so a guest's hotel experience is not negatively affected ("Press Release: Hyatt," 2018).

- The company had a goal to reduce greenhouse gas emissions per square meter, the goal was achieved and the emissions was reduced to $25 \%$ in all its properties ("Press Release: Hyatt," 2018).

- The hotel's fitness centers have a program to recycle earbuds: With this program, the company was able to recycle nearly 65,000 pairs in 2017 with eighty participating Hyatt hotels. The participating hotels provide recycle earbuds to guests, as opposed to single-use earbuds ("Press Release: Hyatt," 2018).

F. Starbucks Coffee

- The company plans to completely eliminate the use of plastic straws by 2020 (Meyer, 2018).

- The company has been considering replacing plastic products with paper goods in order to reduce plastic waste (Koch, 2013).

G. McDonald's Restaurants

- The fast food restaurant chain will stop the use of straws in the United Kingdom and Ireland. Currently the use of plastic straws is approximately 1.8 million per day across the 1,361 restaurants in these two countries. The efforts to eliminate straws is anticipated to be complete by 2019 (Lauren, 2018).

- By 2025, only recycled or eco-friendly products will be used for beverage cups, Happy Meal boxes and other packaging items used by the company (Kukulka, 2018)

Targeted News Service published an article about how InterContinental Hotels Group (IHG) Company is removing straws from all its hotels worldwide (2018). This new initiative will reduce the usage of 50 million single-use plastic straws across each hotel around the world. IHG considers that this effort will lead to complaints from some guests, so it is also looking for biodegradable alternatives, such as offering straws made out paper or food ("IHG to remove plastic straws from hotels worldwide," 2018). The efforts undertaken by the hospitality industry towards sustainability can be seen as positive by society in general; however, some guests may be dissatisfied. Thus, just like the ING Company did, it is indispensable for businesses to examine customer preferences and strive to accommodate to those preferences. 
The waste sorting plan that was created since 1990 in Las Vegas, Nevada, needs some special mention. The Las Vegas hotels and restaurant adopted a waste sorting program, due of the size of the hotels the separation of recycling was extremely difficult, so each property created a recycling program on each of the hotel's receiving docks. The sorting of the waste takes between eight to twenty-four hours per day, it all depends on the waste that is being generated. A company might think that paying labor and constructing a designated area at the dock for the waste sorting to take place might be really expensive, however you will be amazed on how much a hotel was able to save a year due to the onsite recycling waste sorting system. Some of the hotels were not only able to recycle cardboard, glass, aluminum, steel and plastic and avoid hauling fees of $\$ 48,000$ dollars per year; also on the waste sorting process the hotels were able to recover silverware, plates, linens, and salt and pepper shakers that unintentional end up in the garbage either thrown away by guests or employees. The savings to some hotels like Harrah's were about $\$ 60,000$ to $\$ 66,000$ dollars annually because of the above mention items reclaimed (Cartier, 1997). This mixed waste sorting strategy is yet to be adopted in many hotels in the world, even it has been very successful in Las Vegas's hotels for the last 30 years, although is still a lot lack of understanding and information about the savings a recycling program might generate to a hospitality business.

\section{Ecolabelling: The LEED certification}

As hotels, restaurants, resorts, and casinos we can create a culture in our guests to be ecofriendly. By doing that the culture of recycling will spread out through the world. A hospitality business that currently is mindful about the environment will gain a higher status or good fame amongst its competitors, however the company could gain a prestigious status if the business looks for a LEED certification. To receive LEED certification, the company must submit a document to the US Green Building Council (USGBC) with the compliance LEED goals which are to conserve energy, recycle materials, conserve water, reduce the negative effects on the local environment and lastly, provide a healthy indoor environment for employees (Russell, 2007). There are four levels on the LEED certification that a building could qualify depending on the green innovations. How those innovations reduce operating cost, improve the performance or help the environment (Matisoff, Noonan, \& Mazzolini, 2014). Depending on the percentage of the building's innovations is the level the property may obtain. A score of $40 \%$ to $50 \%$ would be a Certified level, $50 \%$ to $60 \%$ would be Silver, $60 \%$ to $80 \%$ would be Gold and over $80 \%$ would be Platinum (Russell, 2007). Those percentage (levels) could be achievable by a hospitality company with seven different categories, they are the following (Johnston \& Breech, 2010);

- Sustainable Sites, which relates to buildings that are located in a good location, where guests can get to the hotel by using public transportation. This will help reduce air pollution. The "heat island" effect could be reduced by if the sustainable site has a covered parking garage, greener areas or a living green roof.

- Water Efficiency, a percentage can be accumulated by having low-flow fixtures, low-water irrigation system or reuse water system.

- Energy and Atmosphere, a building will be able to obtain a high percentage if it utilizes Energy Star standards such as solar panels system, or green power purchases.

- Material and Resources, this category is one of the main reasons of this research paper because it includes how the building is recycling material and also waste management in food, plastics, cardboard, paper, aluminum, and glass.

- Indoor Environmental Quality, some examples that could give percentage points are using paints and cleaning products that do not release harmful chemical, also providing interior spaces with natural light of the day and views. Good heating or cooling systems will also fall into this category.

- Innovation in Operations, this category is also important to consider for percentage points towards a certification because it allows the businesses, employees or partners to create or develop a project to address an eco-friendly feature in the building, and the feature doesn't necessarily has to be found in the previously mentioned categories.

- Regional Bonus Points, this last category like four and six are also important regarding this research paper because bonus percentage points will be awarded to those buildings that are located in a nearby area with an environmental problem. For example, in this case the Coeur d'Alene Resort will obtain bonus percentage points by reducing waste (plastic, food, paper, cardboard and aluminum.) that goes into the lake. LEED will recognize the importance and the sensitive of the matter and how the building addresses the issue by creating an eco-friendly plant to reduce the environmental problem. 
As of 2014, there were approximately 209 hotels with a Leadership in Energy and Environmental Design (LEED) certification and fifteen others in the process of becoming LEED certified in the United States, compared to six LEED certified hotels in Canada (Cornell, 2014). There are thousands of hotels, restaurants, casinos, convention centers and other businesses in the hospitality industry throughout the world that are not taking steps toward sustainability or seeking an LEED certification. This last paragraph discusses the importance of an LEED certification and how a hospitality company can obtain this certification. There are six reasons why more hotels will be LEED certified in the future (Cornell, 2014):

1. Guests and consumers are beginning to expect and demand business to be eco-friendlier and more sustainable throughout their facilities.

2. Meeting LEED specifications is not necessarily more expensive. There are different cases where a company will reach an LEED standard at no additional cost, such as reusing or recycling materials. A standard such as this one will have little to no cost for a company.

3. Hotels with LEED certifications are less costly to operate because of the waste management; this department will control, reduce and recycle the hotel's products such as plastic, paper, glassware and other materials.

4. In an LEED certified hotel enjoys higher revenue than hotels without any LEED certifications. This is based on research examining 93 LEED certified hotels and 514 comparable competitors without LEED certification comparing the revenue generated per available room, there was a clear advantage for LEED certified hotels, who experienced higher revenue in the first two years post-certification.

5. An LEED certified hotel is able to provide a better overall experience to consumers than non-LEED certified hotels. As an example, the Andaz Hotel by Hyatt got rid of plastic water bottles by offering refillable thermal water bottles to guests, which they can keep as a souvenir at the end of their stay.

6. LEED certification is a dominant trend among hotels, such as the Marriott, Starwood Hotels Resorts, Hyatt and those previously mentioned. Eventually, this will force other hotels to follow the trend so as to not stay behind.

It is extensively recommended for a company to obtain an LEED certification to stay competitive in the hospitality market. Like it was stated before this will give a prestigious name among the competitors because guests are now mindful about the environment and they will seek a hospitality property that is eco-friendly. Besides the prestigious name that a LEED certification would gain for a hospitality hotel, there are other multiple benefits previously stated in this propaper. Some of those benefits are lower operating cost (lower maintenance cost, lower utility bills), increased property value (higher market value, higher lease-up rate), healthier and safer for guests and employees, also certified recognition of eco-friendly practices (Johnston, \& Breech, 2010).

\section{Discussion}

Roughly half of the solid plastics that are produced in the world annually, including a total of 150 million tons of plastic waste, are thrown away every year (Garcia \& Robertson, 2017). The production and waste of plastic solids in the United States, accounts for twenty percent of the worldwide amount of generated in plastic solid waste. The article, "The Future of Plastics Recycling" (2017) describes the importance of recycling plastic solids, since it helps the environment and also represents a great opportunity for economic growth. The value for the United States' landfill packaging material waste is estimated to be 11.4 billion dollars, and 8.3 billion dollars of it is from plastic waste. The recycling of plastic waste can create energy savings for the country, 130 million kilojoules of energy can be saved if one ton of plastic is recycled (Garcia \& Robertson, 2017). 3.5 billion barrels of oil, which has an approximate value of 176 billion dollars, it could also be the equivalent value for the recycling of all global plastic solid waste. A hospitality business, such a resort or hotel can produce tons of plastic waste throughout the year, investors or hotel's managers of these companies can become partners with companies that recycle plastic and that waste can be turned into revenue. This partnership will not only create higher revenue by reducing daily cost operations, but it will also help the environment.

There is currently 100 million tons of plastic floating in the ocean, although the population and hospitality industries are currently recycling plastic, it is estimated that some of it slips through the cracks and ends up in the water from the recycling facilities (Schlossberg, 2016). Like it was stated before, there are many hotels, resorts, restaurants and casinos located nearby or by the beach, plastic pollution can take out business many hospitality destinations because of the waste. Hospitality businesses nearby should create a marketing campaign with guests and employees about the importance of recycling. The message will be easier to be delivered to the guests and employees and it will create a consciousness on recycling. Currently, in the United States, there is a 
little less than a third of plastic collected for recycling, although plastic waste is one of the easiest and most efficient solid to recycle (Schlossberg, 2016).

Schlossberg describe in the article, "A steep for bottle water" (2016) how a Doctor by the name Jambeck estimates that nearly half of plastic wastes come from Asia. The main countries are China, Indonesia, the Philippines and Vietnam, these countries are well known for beautiful beaches, reefs, lakes, rivers and full of resorts and hotels. The problem consists of poor waste management; if this problem persists the number could double by the year of 2025 and will end up polluting the beaches and reefs. The wild animals that live in the ocean will also be at risk of extinction due to plastic pollution.

In an article published by Instablogs ("Seven Innovative plans to reduce plastic waste," 2011), the following ideas for wastage reduction are mentioned for practical use by the industry:

- Creating a tax for the use of plastic bags or banning their use.

- Stopping the use of plastic bottles on hotel property. Guests can be encouraged to use glassware or paper cups to serve drinking water, soda, juice, or other beverages. The property can encourage guests by providing re-washable stainless-steel containers and by charging a small fee to refill the container, as opposed to paying for each plastic bottled beverage. This initiative can help stop or reduce the usage of plastic bottles in a hotel property by giving guests a choice to either purchase a stainless-steel container for personal reuse or return it to the hotel so other guests can use it.

- Stopping the usage of plastic utensils: this can be accomplished if businesses provide only silverware to guests which can be returned to the staff or silverware stations set up around the property; this would take away a guest the option of using plastic utensils.

- If businesses begin to use paper bags instead of plastic bags, guest will use what is available to them. A better alternative to reduce the use of plastic bags is encouraging guests to avoid its use by making them conscious of the impact their waste footprint will have on the environment. One-way restaurants can do this is by suggesting to guests to finish their meals as much as possible to avoid leftovers and to go containers and bags.

- Stopping the use of any plastic containers to avoid plastic waste and opting for eco-friendly containers.

- Kitchen areas can avoid using non-stick cookware. This type of cookware is made of a special type of plastic, so this increases the production of plastic, which will lead to usage and waste of plastic. Restaurants and kitchens in the hospitality industry can replace nonstick cookware with aluminum cookware to reduce the production of plastic. Rice cookers are also made of plastics, and a better alternative would be pressure cookers. It is also important to buy microwaves that are not only functional with plastic containers, but also with anything made of aluminum.

- Avoid buying produce that is packaged in hard plastic containers or plastic bags. Nowadays there are many supplier companies who in their efforts to be eco-friendly are avoiding packaging produce or products with plastic, and instead use cardboard, wood or paper.

Another great idea for the hospitality businesses when it comes to beverage bottles that are made of plastics is to turn them from bottles to trees. According to an article published by Khurram, Burney, Morrisey and Jacobs "Bottles to trees" (2017), beverage bottles could be a great alternative as a nursery growing container for reforestation. The hotels and restaurants could use the plastic bottles to grow green areas either outside of the facility or the inside. The article describes two experiments conducted using plastic containers or bottles to grow trees and the planting, growing and harvest process was better in the trees using a plastic bottle compared to modern nursery containers or polybags. Many hotels like the Bellagio Resort and Casino in Las Vegas are growing their own organic herbs on the top of the roofs for their restaurants, this could be a great idea for those hotels to utilize the plastic bottles in order to grow better plants. This will save the resorts money whenever buying nursery containers or polybags.

Based on (Hill, 2011), other ideas to minimize wastage include:

- An energy-intensive plastic chipper that usually runs for long periods of time can be programmed to run only during off-peak hours, allowing the company to save some money.

- Timing devices could be installed on baseboard heaters in offices, hotel rooms, restrooms, meeting rooms and any other facilities so as to shut them off when they are not being used.

- Replacing high-flow toilets with low-flow models, this will save a lot water usage in a hotel, especially if installed in the rooms.

- Encouraging companies to replace Styrofoam or plastic cups with environmentally sustainable cups like paper or glass cups for visitors, while requiring the hotel's staff to bring their own eco-friendly beverage cup.

- To eliminate paper waste, the company could switch to an online newsletter. 
- $\quad$ Reviewing the mailing list of each business to eliminating duplications or switching to only sending emails. This will help avoid the costs of printing paper, ink, and postage.

Finally, assigning individual responsibility has no substitute (Korstanje \& George, 2012). A company can encourage its employees to be eco-friendly by reminding them: to turn off all lights when not needed; to only change plastic bags in a trash can when needed; to stop offering straws to guests unless a guest requests one; to print documents only when absolutely necessary; to recycle batteries and cell phones; and many other policies that can influence the lifestyle of employees and guests. If a company explains the savings to the staff, they will be more responsible when it comes to recycling and using plastic as well as other materials (Korstanje \& George, 2015).

\section{Conclusion}

Sustainability could be defined in different ways; in the cases of a business it could mean "best practices," that have to do with anything that helps the company in saving money while being efficient and leaner in its operation process (Lewis, 2011). Recycling and reducing wasteful consumption are key steps in this regard; businesses should reduce their impacts upon the environment by calibrating consumption and reuse of their resources (Lewis, 2011).

It is important to revisit the three main benefits that recycling does for the planet's environment and resources which are: it dramatically reduces the amount of waste sent to dumpsites, increases the conservation of energy and natural resources, and lastly it is the easiest and simple way of us as a society to contribute in a positive way to tackle the climate change (Bolton, McCart, \& Morrish, 2007). It takes approximately eight times more energy to fabricate plastic bottles from virgin polymer than it does to use recycled materials. A research conducted by WRAP concluded that United Kingdom's recyclables such as paper, cardboard, glass, plastics, aluminum and steel saves around 10 and 15 million tons of greenhouse gases per year, we can compare these savings to greenhouse gases that 3.5 million cars in the UK emitted on the roads yearly (Bolton et al, 2007).

Many hospitality businesses are visited because of their location, either because they are located in or near a beautiful beach, mountain, lake, river or cosmopolitan city. However, in order to keep the business going the hospitality business needs to reduce the waste otherwise, they might lose the surroundings because of the pollution. This was the case of the 334-room Coeur d'Alene Resort located by the lake, the resort was producing 50 tons of recyclables annually, however the hotel didn't have a recycling program which all the waste was producing mountains of trash daily. Most of this trash could have been recycled yet it was destined for burial at the landfill. In January 2017 the resort created a program to recycle the waste produced by the bars, restaurants, catered events and service elevators. The aggressive eco-friendly program minimizes the impact of the garbage that was being dumped in the landfill by collecting and recycling the 50 tons of material that includes recycling paper, aluminum, and plastic (Erickson, 2018).

There are some interesting opportunities of further research regarding plastic waste and recycling. For example, hotels, restaurants, casinos, bars, and nightclubs still need to find out how reducing the plastic products in their establishments is affecting the guest. Starbucks Coffee Company or McDonald's Company could be an example of future research opportunities of how the stopping of straws has impacted the guest, have this cause any inconvenience to the guest or staff? Is it really worth it to stop the usage of plastic straws, meaning are they losing consumers because of the initiative? So far similar restaurants like Dunkin' Donuts, The Coffee Bean and Tea Leaf, Burger King, Wendys and other fast food restaurants have not yet taken the initiative to stop the usage of plastic straw, what is the reason? Are they waiting to see if McDonald's or Starbucks Company will fail with the initiative and lose consumers, so the competition can take advantage? Those are some of the questions future research could go more in depth to find out some answers.

A final thought: since marketing is expensive for a hospitality business, how about if the businesses can do publicity without spending much and this can also help the environment? Good publicity is one of the benefits of recycling (Zank, 2016). An industry does not realize how beneficial it can be to publicize to inform guest about the recycling programs the hotel or resort is currently implementing to protect the environment. Many guests will see it as a good cause and will choose to stay there, rather than stay at a hotel or resort that is not implementing anything to recycle and is only damaging the environment.

\section{Appendix A. Supplementary material}

Supplementary data associated with this article can be found, in the online version, at https://doi.org/10.14254/jems.2019.4-1.1 


\section{Funding}

The authors received no direct funding for this research.

\section{Citation information}

Ramirez, A., \& George, B. (2019). Plastic recycling and waste reduction in the hospitality industry: Current challenges and some potential solutions. Economics, Management and Sustainability, 4(1), 6-20. doi:10.14254/jems.2019.4-1.1.

\section{References}

Anantara, Avani Hotels to end the use of plastic straws. (2017). TradeArabia, p. TradeArabia, Dec 21, 2017.

Anonymous. (2009). CityCenter's Aria and Vdara First Las Vegas Hotels to Achieve LEED(R) Gold Certification. PR Newswire, p. 14.

Anonymous. (2009). Eliminating Bottled Water. Sacramento Observer, p. F3A.

Baker, M., Davis, E., \& Weaver, P. (2014). Eco-friendly Attitudes, Barriers to Participation, and Differences in Behavior at Green Hotels. Cornell Hospitality Quarterly, 55(1), 89-99.

Begley, S. (2008, July 14). True or false: Global warming is A cause of this year's extreme weather. Newsweek, 152 Retrieved from http://ezproxy.library.unlv.edu/login?url=https://search.proquest.com/docview/21425056 8? accountid=3611

Bolton, B., McCart, P., \& Morrish, L. (2007). The question / The solutions. Caterer \& Hotelkeeper, 197(4458), 66.

Cartier, D. (1997). Mixed waste sorting in Las Vegas. BioCycle, (1), 32-33.

Cornell, C. (2014). Six reasons hotels are taking the LEED. National Post (Index-only), p. N/a.

Corral-Verdugo, V., \& Frías-Armenta, M. (2016, August). The sustainability of positive environments. Environment, Development and Sustainability, 18(4), 965-984. doi: https://doi.org/10.1007/s10668-015-9701-7

County's waste agency helps hotels recycle. (Onondaga County, New York) (Brief Article). (1999). American City \& County, 114(15), 17.

Diaz, J. (2012). Save the Plastic Bag Coalition v. City of Manhattan Beach: California Supreme Court Answers More Than "Paper or Plastic?" in Major Decision on Corporate Standing under CEQA. Ecology Law Quarterly, 39(2), 627-634. Retrieved from http://ezproxy.library.unlv.edu/login?url=http://search.ebscohost.com/login.aspx?direct=tr ue $\& \mathrm{db}=$ aph \&AN=83761852\&site=ehost-live

Du Pisani, J.A. (2006). Sustainable development - historical roots of the concept. Environmental Sciences, 3(2), 83-96.

EPA Awards MGM Resorts for Food Recycling Program. (2011). Food and Beverage Close - Up, pp. Food and Beverage Close - Up, Nov 18, 2011.

Erickson, K. (2018). Resorting to recycling. Journal of Business, 33(18), 11-16.

Garcia, J., \& Robertson, M. (2017). The future of plastics recycling. Science (New York, N.Y.), $358(6365), 870-872$.

Goldstein, K.A. and Primlani, R.V. (2012). Current trends and opportunities in hotel sustainability. Retrieved from www.hospitalitynet.org/news/4054752.html.

Golubovskaya, M., Robinson, R. N. S., \& Solnet, D. (2017). The meaning of hospitality: Do employees understand? International Journal of Contemporary Hospitality Management, 29(5), 12821304. doi: https://doi.org/10.1108/IJCHM-11-2015-0667

Hamilton, T. (2012). Scoring the world's economic powerhouse. Corporate Knights. The Magazine for Clean Capitalism. Sept. 18, 2012.

Hertzfeld, Esther. (2010). Make guest recycling easy for better compliance. (Hotel Operations: Housekeeping Services). Hotel \& Motel Management, 225(12), 22-23. 
Hill, J. (2011). Online forum offers ideas to kick-start Sustainability initiatives within smaller companies. Corporate Report Wisconsin, 26(4), 10. Retrieved from http://ezproxy.library.unlv.edu/login?url=https://search.proquest.com/docview/85125242 2 ?accountid $=3611$

Holmes, B. (2017). Towards zero waste. New Scientist, 235(3135), 42.

Hotel encourages staff to create beautiful world of art using trash. (2010). Instablogs, p. Instablogs, Jul 9, 2010.

IHG to Remove Plastic Straws from Hotels Worldwide. (2018, October 11). Targeted News Service (USA). Available from NewsBank: https://infoweb-newsbankcom.ezproxy.library.unlv.edu/apps/news/documentview? $\mathrm{p}=\mathrm{AWNB} \&$ docref=news $/ 16 \mathrm{~F} 0266031387 \mathrm{AA} 8$.

International Plastic Recycling Groups Announce Global Definition of Plastics Recyclability. (2018, July 12). Targeted News Service (USA). Available from NewsBank: https://infowebnewsbank-com.ezproxy.library.unlv.edu/apps/news/documentview?p=WORLDNEWS\&docref=news/16D278A44A2A3028.

International Union for the Conservation of Nature and Natural Resources (1980). World conservation strategy. Retrieved from https://portals.iucn.org/library/efiles/documents/WCS-004.pdf

Johnston, D., \& Breech, P. (2010). An Introduction to LEED Certification for Hotels. Lodging Hospitality, p. Lodging Hospitality, Oct 6, 2010.

Jones, P., Hillier, D., \& Comfort, D. (2014). Sustainability in the global hotel industry. International Journal of Contemporary Hospitality Management, 26(1), 5-17. Retrieved from http://ezproxy.library.unlv.edu/login?url=https://search.proquest.com/docview/14678058 55 ?accountid $=3611$

Khurram, S., Burney, O. T., Morrissey, R. C., \& Jacobs, D. F. (2017). Bottles to trees: Plastic beverage bottles as an alternative nursery growing container for reforestation in developing countries. PLoS ONE, 12(5), 1-21. https://doi.org/10.1371/journal.pone.0177904

Koch, Wendy. (2013). At Starbucks: Paper or plastic? (MONEY)(Starbucks Corp.). USA Today, p. 02B.

Korstanje, M. E., \& George, B. (2012). Sustainable Tourism and Global Warming: panacea, excuse, or just an accidental connection?. Worldwide Hospitality and Tourism Themes, 4(4), 383-394.

Korstanje, M. E., \& George, B. (2012). Global warming and tourism: chronicles of apocalypse?. Worldwide Hospitality and Tourism Themes, 4(4), 332-355.

Korstanje, M. E., \& George, B. (2015). The Impossible Sustainability: Applications of relational perspective in tourism fields. Ecoforum Journal, 4(1), 2-9.

Kukulka, A. (2018). Local coffee shops, restaurants consider eco-friendly alternatives to plastic straws. TCA Regional News, p. TCA Regional News, Jul 25, 2018.

Lauren Said-Moorhouse. (2018). McDonald's to scrap plastic straws in UK and Ireland. CNN Wire, p. CNN Wire, June 15, 2018.

Le Page, M. (2018). Plastic bag ban is no plan for a green future. (climate change mitigation) (Insight. New Scientist, 237(3161), 25-25.

Lewis, D. (2011, March). Sustainable meaning. ColoradoBiz, 38(3), C3-C4. Retrieved from http://ezproxy.library.unlv.edu/login?url=https://search.proquest.com/docview/85809237 4?accountid=3611

Lindsey, T. (2011, March). Sustainable principles: Common values for achieving sustainability. Journal of Cleaner Production, 19(5), 561-565.

Liu Qinghou, \& Min Yunbao. (2012). Waste plastic recycling process method. Marriott International 2011-2012 Sustainability Report Highlights Youth Employment Initiatives and Preserving the Environment. (2012). PR Newswire, p. PR Newswire, Aug 28, 2012.

Matisoff, D., Noonan, D., \& Mazzolini, A. (2014). Performance or marketing benefits? The case of LEED certification. Environmental Science \& Technology, 48(3), 2001-7.

Meyer, Z. (2018). Starbucks plans to scrap plastic straws by 2020. USA Today, p. 01B. 
MGM Resorts International Joins American Business Act on Climate Pledge. (2015). PR Newswire, p. PR Newswire, Aug 25, 2015.

MGM resorts international ranked one of the top 100 greenest companies by newsweek magazine. (2014, Jun 06). PR Newswire Retrieved from http://ezproxy.library.unlv.edu/login?url=https://search.proquest.com/docview/15331686 70 ?accountid $=3611$

Milios, Leonidas, Davani, Aida E., \& Yu, Yi. (2018). Sustainability Impact Assessment of Increased Plastic Recycling and Future Pathways of Plastic Waste Management in Sweden. Recycling, 3(3), 33-0.

Millar, M., \& Baloglu, S. (2011). Hotel Guests' Preferences for Green Guest Room Attributes. Cornell Hospitality Quarterly, 52(3), 302-311.

Monterey Bay Aquarium Builds Life-Sized Blue Whale Art Installation Made From Discarded SingleUse Plastic to Raise Awareness About Ocean Pollution. (2018, October 11). Targeted News Service (USA). Available from NewsBank: https://infoweb-newsbankcom.ezproxy.library.unlv.edu/apps/news/documentview? $\mathrm{p}=$ AWNB\&docref=news/16F0286F9C75EB50.

Pacheco, Ronchetti, \& Masanet. (2012). An overview of plastic recycling in Rio de Janeiro. Resources, Conservation \& Recycling, 60, 140-146.

P. J. (1958, October 05). Travel association studies tourism census. New York Times (1923-Current File) $\quad$ Retrieved from http://ezproxy.library.unlv.edu/login?url=https://search.proquest.com/docview/11 4525007 ? accountid $=3611$

Plastics - the environmental solution, not the problem. (1992, March 30). The Christian Science Monitor (Pre-1997 Fulltext) Retrieved from http://ezproxy.library.unlv.edu/login?url=https://search.proquest.com/docview/29119623 4? accountid=3611

Povich, E. (2018). Starbucks to Scrap Plastic Straws. TCA Regional News, p. TCA Regional News, Jul $10,2018$.

Press Release: Hilton Worldwide Deepens Global Commitment to Waste Solutions and Recycling Through Partnership with Clean the World. (2015). Dow Jones Institutional News, p. Dow Jones Institutional News, Apr 17, 2015.

Press Release: Hyatt Announces Global Efforts to Reduce Single-Use Plastics. (2018). Dow Jones Institutional News, p. Dow Jones Institutional News, Jul 9, 2018.

Press Release: Marriott International Unveils Global Sustainability and Social Impact Commitments to Deliver Positive Change. (2017). Dow Jones Institutional News, p. Dow Jones Institutional News, Oct 31, 2017.

Rochman, C. M., Browne, M. A., Halpern, B. S., Hentschel, B. T., Hoh, E., Karapanagioti, H. K., ... \& Thompson, R. C. (2013, February 14). Policy: Classify plastic waste as hazardous. Nature, 494(7436), 169-171. https://doi.org/10.1038/494169a

Russell, K. (2007). LEED Certification. Computerworld, 41(36), 44.

Sardon, H., \& Dove, A. (2018). Plastics recycling with a difference. Science (New York, N.Y.), $360(6387), 380-381$.

Schlossberg, T. (2016, November 01). A steep price for bottled water. New York Times. Retrieved from

http://ezproxy.library.unlv.edu/login?url=https://search.proquest.com/docview/18343392 64? accountid=3611

Shamah, D. (2008, Oct 30). Israel's building its first 'eco-friendly' town. Washington Jewish Week Retrieved from http://ezproxy.library.unlv.edu/login?url=https://search.proquest.com/docview/22086260 7? accountid $=3611$

Sloan, P., Legrand, W., Chen, J., \& ScienceDirect. (2009). Sustainability in the hospitality industry: Principles of sustainable operations (1st ed.). Amsterdam; Boston: ButterworthHeinemann/Elsevier 
Sloan, P., Legrand, W., \& Chen, I.J. (2013), Sustainability in the Hospitality Industry: Principles of Sustainable Operations, Routledge, London.

Seven Innovative plans to reduce plastic waste. (2011, October 25). Instablogs (Shimla, India). Available from NewsBank: https://infoweb-newsbankcom.ezproxy.library.unlv.edu/apps/news/documentview? $\mathrm{p}=$ AWNB\&docref $=$ news $/ 158 C A F 6 D D 5 F C F 7 A 0$

The Ritz-Carlton Hotel Company Introduces Environmentally-Friendly Water Bottles at its North American and Select Caribbean Hotels; A Breakthrough in Reducing Plastic Bottle Use. (2010). Targeted News Service, p. Targeted News Service, Jun 17, 2010.

Valenzuela, F., \& Böhm, S. (2017, March). Against wasted politics: A critique of the circular economy. Ephemera, 17(1), 23-60. Retrieved from http://ezproxy.library.unlv.edu/login?url=https://search.proquest.com/docview/18887057 54?accountid=3611

Wagner, T. (2017). Reducing single-use plastic shopping bags in the USA. Waste Management, 70, 312.

Wenche A., Tuomas A., Kirsi A., Andreas K., \& Bjorn A. (2017). Project sustainability strategies: A systematic literature review, 35(6), 1071-1083

Which are the most sustainable countries in the world? (2012, September 19). PR Newswire Retrieved

from http://ezproxy.library.unlv.edu/login?url=https://search.proquest.com/docview/10409662 33? accountid=3611

Zank, A. (2016, April 21). Road builders saving money, resources with recycling practices. The Daily Reporter Retrieved

from http://ezproxy.library.unlv.edu/login?url=https://search.proquest.com/docview/17843678 97 ? accountid $=3611$

Zisman, J. (2018, 03). Satisfy the needs of your multi-generational workforce. Employee Benefits and Wellness Excellence Essentials, Retrieved from http://ezproxy.library.unlv.edu/login?url=https://search.proquest.com/docview/20437557 07?accountid=3611

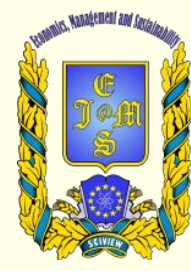

(C) 2016-2019, Economics, Management and Sustainability. All rights reserved. This open access article is distributed under a Creative Commons Attribution (CC-BY) 4.0 license.

You are free to:

Share - copy and redistribute the material in any medium or format Adapt - remix, transform, and build upon the material for any purpose, even commercially.

The licensor cannot revoke these freedoms as long as you follow the license terms.

Under the following terms:

Attribution - You must give appropriate credit, provide a link to the license, and indicate if changes were made.

You may do so in any reasonable manner, but not in any way that suggests the licensor endorses you or your use.

No additional restrictions

You may not apply legal terms or technological measures that legally restrict others from doing anything the license permits.

Economics, Management and Sustainability (ISSN: 2520-6303) is published by Scientific Publishing House "CSR",

Poland, EU and Scientific Publishing House "SciView", Poland

Publishing with JEMS ensures.

- Immediate, universal access to your article on publication

- High visibility and discoverability via the JEMS website

- Rapid publication

- Guaranteed legacy preservation of your article

- Discounts and waivers for authors in developing regions

Submit your manuscript to a JEMS at http://jems.sciview.net or submit.jems@sciview.net

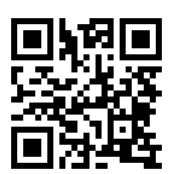

